Roads to Health 


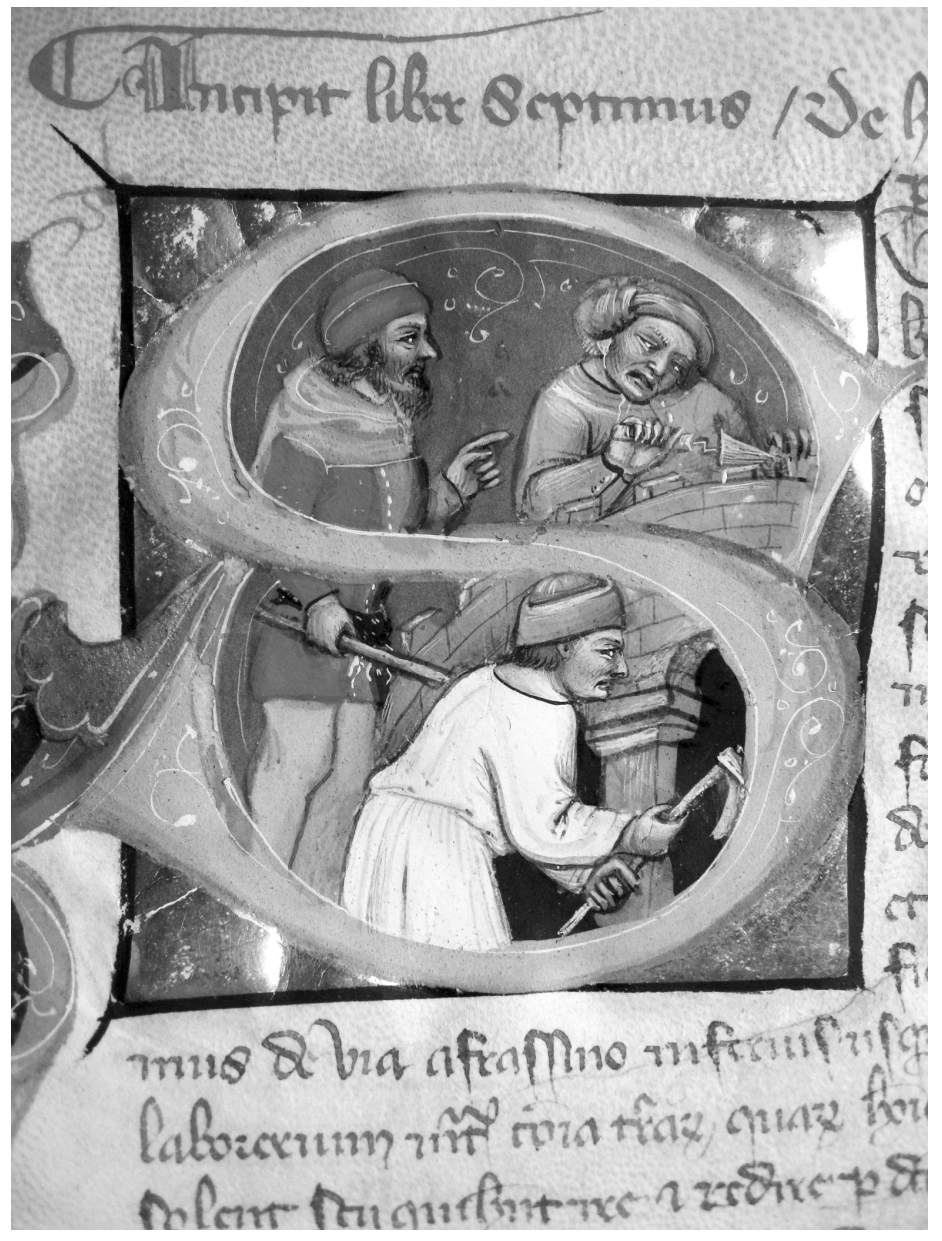

Frontispiece. Bologna's fango officials. Bologna's road master was known as the mud or dirt (fango) official since the thirteenth century. In this miniature from the city's 1376 redaction of the statutes he is depicted holding a cane and supervising two masons. As elsewhere in Italy, in Bologna the official's main task was to build and maintain urban infrastructures, which in turn put him at the forefront of fighting health and safety hazards. Source: Archivio di Stato di Bologna, Governo 46, fol. 303v. Photograph by the author. By kind permission of the Ministero dei beni e delle attività culturali e del turismo-Archivio di Stato di Bologna. 


\title{
ROADS TO HEALTH
}

\author{
Infrastructure and Urban Wellbeing \\ in Later Medieval Italy
}

\section{G. Geltner}

\author{
PENN \\ UNIVERSITY OF PENNSYLVANIA PRESS \\ PHILA DELPHIA
}




\section{THE MIDDLE AGES SERIES}

\section{Ruth Mazo Karras, Series Editor}

Edward Peters, Founding Editor

A complete list of books in the series is available from the publisher.

\section{Copyright (C) 2019 University of Pennsylvania Press}

All rights reserved. Except for brief quotations used for purposes of review or scholarly citation, none of this book may be reproduced in any form by any means without written permission from the publisher.

$$
\begin{gathered}
\text { Published by } \\
\text { University of Pennsylvania Press } \\
\text { Philadelphia, Pennsylvania I9I04-4II2 } \\
\text { www.upenn.edu/pennpress }
\end{gathered}
$$

Printed in the United States of America on acid-free paper

$$
\text { I } 35579 \text { IO } 86442
$$

\section{Library of Congress Cataloging-in-Publication Data}

Names: Geltner, G. (Guy), author.

Title: Roads to health: infrastructure and urban wellbeing in later medieval Italy / G. Geltner.

Other titles: Middle Ages series.

Description: Ist edition. | Philadelphia: University of Pennsylvania Press, [2019] | Series: The Middle Ages series | Includes bibliographical references and index.

Identifiers: LCCN 20I8053I09| ISBN 97808I225I357 (hardcover: alk. paper) | ISBN 08I225I350 (hardcover: alk. paper)

Subjects: LCSH: Urban health-Italy-History-To I50o-Case studies. | Public health-Italy-History-To I500-Case studies. | Public health laws-Italy-History-To I500-Case studies. | City dwellers-Health and hygiene-Italy-History-To I50o-Case studies. | Lucca (Italy)_Social conditions-To I500. | Bologna (Italy)—Social conditions-To I500. | Pinerolo (Italy)—Social conditions-To I500.

Classification: LCC RA566.5.I8 G45 2019 | DDC 362.1/0420937-dc23

LC record available at https://lccn.loc.gov/2018053109 
For

Ingrid Bleynat

Rupal Sanghvi

Alon Shepon

Markus Stauff

Altissima quaeque flumina minimo sono labi 
